\title{
EXPERIMENTAL MODEL FOR PREDICTING DRAFT AND POWER REQUIREMENTS OF SIMPLE TILLAGE TOOLS
}

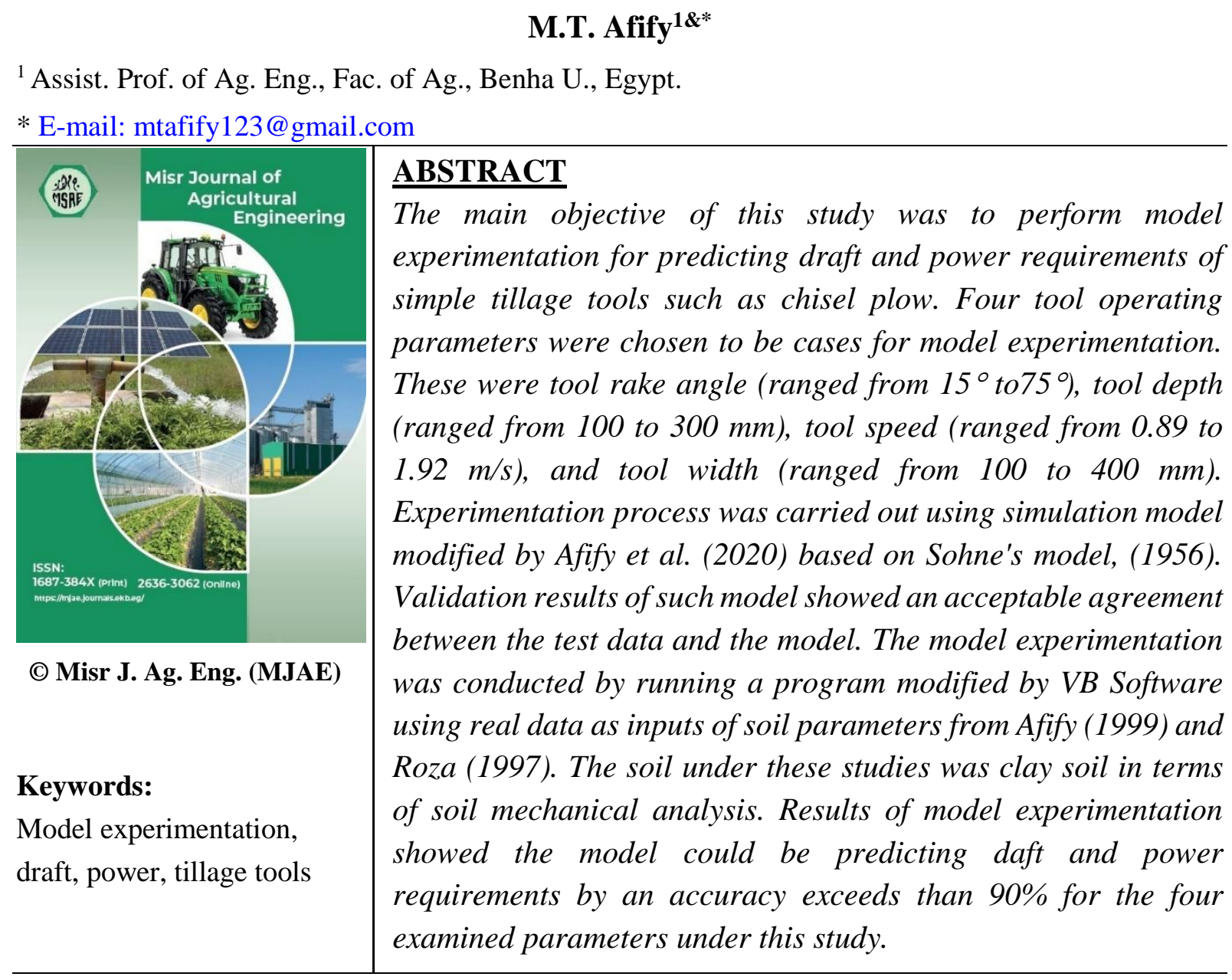

\section{INTRODUCTION}

I nput energy considered one of the important factors affected on the performance efficiency of the tillage tools (Gill and Vanden Berg, 1968). According to the current prices, Egyptian farmers consumed fuel by about 1625 million pounds (108.33 million \$) for tilling 6.5 million hectares (CAPMS, 2019). This estimation based on the average value of fuel need to cultivate one hectare is 35 liters for clay soil by traditional method (Afify et al. 1999). Results of previous studies in terms of power requirements of tillage tools showed that soil cultivating process consumes more than half of the energy needed to grow agricultural products (Abd El Wahed, 2007). This higher energy consumption because of the motion of large amount of soil mass and inefficient methods of energy transfer to the soil (Al-Hamed et al., 2014, and Tong and Moayad, 2006). Modern agriculture practices need a challenge technique to determine energy requirements of tillage tools. Therefore, simulation models are an efficient technique for evaluating the performance of tillage tools. Many researches have been carried out in developing computer-based models and simulation programs for determining energy requirements of tillage tools (Shahgholi et al., 2019; Moeenifar et al., 2014; Kheiralla et al., 2004; Al-Hamed et al., 2014; Akbarnia et al., 2014; Abu-Hamdeh et al., 2003; and Abd El Wahed, 2007). On the other hand, few of these studies performed model experimentation 
process. The subject of model experimentation is not new and is widespread in fields like natural sciences and economics. Experimentation has also prevailed in literature on strategic role management and transitions management focusing on searching, learning and experimenting for sustainable development (Bocken et al., 2018). Therefore, the main objective of this study was to accomplish model experimentation for predicting draft and energy for tillage tools using four examined tool parameters.

\section{MATERIALS AND METHODS}

\subsection{Model Development}

Under this study, Visual Basic was used as a computer programing langue to develop a model based on Sohne's model for simple tillage tools. The effect of soil-tool interaction on predicting draft of tillage tools was investigated. The model is an interactive program where the user is prompt to enter his relevant input data for the model. A set of screens, object buttons, scroll bars, and menus which available at Visual programming were used to design the form. The objects can be positioned on a form, and their behaviors are described through the use of a scripting language associated with each one. The structure of building the model consisted of interrelated screens and tasks arranged in a logical and easily understandable in order to form an integrated and complete unit as showed in Figure (1). A simulation model that has been modified by Afify et al. (2020) was used to perform model experimentation for predicting draft and power requirements. The model was designed for simple tillage tools such as chisel plow as it is the famous plow used under Egyptian conditions.
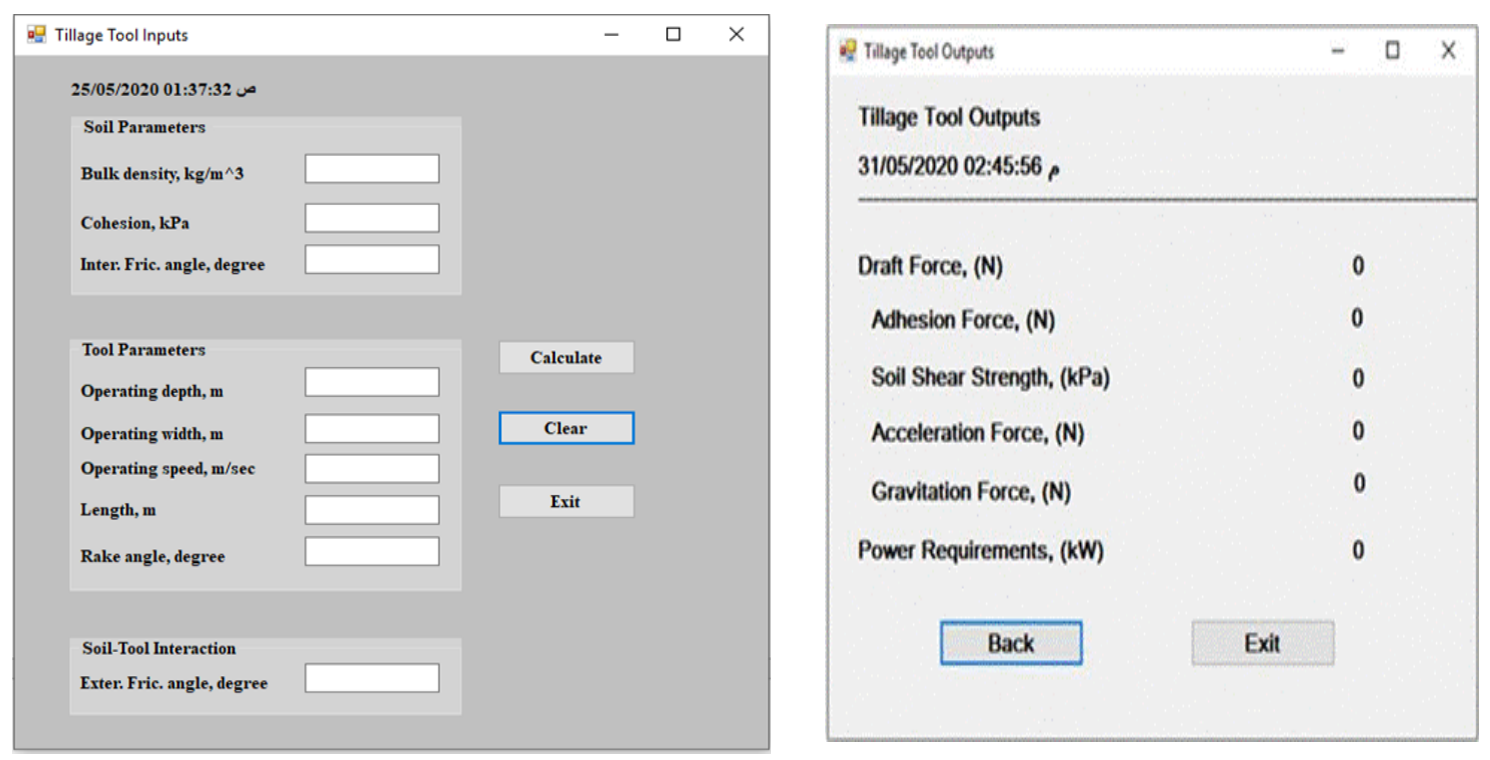

Figure (1): Screenshots for input and output interfaces of the modified program for predicting draft force.

The draft under such model was predicting through calculating the forces resulting from soiltillage tool interactions based on Sohne's model. All variables were defined using the Visual Basic language to calculate the draft and consequently, power requirements. After creating the procedures and functions, equations from mathematical analysis of Sohne's model were used to calculate the draft. However, the predicting power requirements of tillage tools was estimated based on draft and tool speed using equation of ASAE, (1998). The verifying procedure was carried out using data from previous studies available in literature (Akbarina et al., 2014; 
Ibrahmi et al., 2014; Ucgul et al., 2014; Fielke, 1988; Zang et al., 2018; Moeenifar et al., 2014). Results of validation showed an acceptable agreement between the test data and the model.

\subsection{Model Experimentation}

Implementation test of any model involves three basic steps. These were desk-checking, debugging, and running real-experimental data to make sure that the model works. These three steps must be conducted to make sure that is realistic works and it's free of errors. Model experimentation performed in order to improve the precision of the results and to limit the model constraints for any examined parameters. Therefore, in this study, the model experimentation was conducted by running a program using real data from Afify (1999) and Roza (1997). Table (1) illustrates the data used as inputs of soil parameters for model experimentation through running the program of modified model. The soil under these studies was classified as clay soil. It has $45.35 \%$ clay, $30.65 \%$ silt, and $24.0 \%$ sand.

Table (1): Some physical and mechanical properties of clay soil used as inputs data (Roza, 1997, and Afify, 1999).

\begin{tabular}{ccccc}
\hline $\begin{array}{c}\text { Moisture } \\
\text { content } \\
(\%)\end{array}$ & $\begin{array}{c}\text { Buck } \\
\text { density } \\
\left(\mathrm{Mg} / \mathrm{m}^{3}\right)\end{array}$ & $\begin{array}{c}\text { Soil } \\
\text { cohesion } \\
(\mathrm{kPa})\end{array}$ & $\begin{array}{c}\text { Internal friction } \\
\text { angle } \\
(\mathrm{deg} .)\end{array}$ & $\begin{array}{c}\text { Soil-metal } \\
\text { friction angle } \\
(\text { deg. })\end{array}$ \\
\hline \multirow{2}{*}{10} & 1.30 & 14.13 & 36.2 & 24 \\
& 1.35 & 15.82 & 37.6 & 24 \\
& 1.41 & 19.96 & 39.8 & 23.9 \\
15 & 1.38 & 10.15 & 28.1 & 23.8 \\
& 1.45 & 12.91 & 29.8 & 23.7 \\
& 1.52 & 13.43 & 31.5 & 23.7 \\
20 & 1.48 & 6.81 & 21.3 & 23.8 \\
& 1.56 & 7.71 & 23.2 & 23.6 \\
& 1.66 & 9.31 & 25.3 & 23.5 \\
\hline
\end{tabular}

3. RESULTS AND DISCUSSION

\subsection{Model Experimentation for Draft}

Figures from (2) to (5) present predicting draft under various levels of tool rake angle, tool depth, tool speed, and tool width, respectively. The effect of tool rake angle on predicting draft at different tool depths and at $(1.38 \mathrm{~m} / \mathrm{s}$ tool speed, $300 \mathrm{~mm}$ tool width, $15 \%$ moisture content, and $12.91 \mathrm{kPa}$ soil cohesion) is shown in Figure 2. Results indicated that the increase in tool rake angle caused increasing in predicting draft for various tool depths. The change in the tool rake angle from $15^{\circ}$ to $75^{\circ}$ produced increasing in the predicting draft by $93 \%, 87 \%, 71 \%, 58 \%$, and $42 \%$ for tool depths of 100, 150, 200, 250, and 300 (mm), respectively. Correlation coefficient for predicting draft with different levels of tool rake angles was 0.85 as polynomial function. These results are similar to the results obtained by Ucgul et al. (2014), and Hamied (2016).

The effect of tool depth on predicting draft at different tool speeds and at ( $45^{\circ}$ tools rake angle, 300 mm tool width, $15 \%$ moisture content, and $12.91 \mathrm{kPa}$ soil cohesion) is shown in Figure 3. The highest values of predicting draft were obtained with tool depth of $300 \mathrm{~mm}$. However, the lowest vales were resulted with the tool depth of $100 \mathrm{~mm}$ under various tool speeds. The change in the tool depth from 100 to $300 \mathrm{~mm}$ resulted in increasing of the predicting draft by $95 \%, 92 \%, 64 \%, 69 \%$, and $76 \%$ for 
tool speeds of $0.89,1.11,1.38,1.67$, and $1.67 \mathrm{~m} / \mathrm{s}$, respectively. Correlation coefficient for predicting draft with tool rake angle was 0.90 as polynomial function. These results are in agreement with pervious results obtained by Akbarnia et al., (2014), Ucgul et al., (2014), and Ibrahmi et al., (2014). The effect of tool speed on predicting draft under different levels of tool depths and at (rake angle of $45^{\circ}$, tool width of $300 \mathrm{~mm}, 15 \%$ moisture content, and $12.91 \mathrm{kPa}$ soil cohesion) is showed in Figure 4. The change in the tool speed from 0.89 to $1.92 \mathrm{~m} / \mathrm{s}$ resulted in increasing of the predicting draft by $94 \%, 78 \%, 82 \%, 65 \%$, and $73 \%$ for tool depths of 100, 150, 200, 250, and $300(\mathrm{~mm})$, respectively. Correlation coefficient for predicting draft with tool speed was 0.92 as polynomial function. These results are in agreement with pervious findings by Aboukarima, (2007), Zang et al., (2018), and Moeenifar et al., (2014).

The effect of tool width on predicting draft under different levels of tool depths and at $\left(45^{\circ}\right.$ of rake angle, tool speed of $1.39 \mathrm{~m} / \mathrm{s}, 15 \%$ moisture content, and $12.91 \mathrm{kPa}$ soil cohesion) is shown in Figure 5. The change in the tool width from 100 to $400 \mathrm{~mm}$ resulted in increasing of the predicting draft by $86 \%, 85 \%, 83 \%, 68 \%$, and $55 \%$ for tool depths of 100, 150, 200, 250, and $300 \mathrm{~mm}$, respectively. Correlation coefficient for predicting draft with tool with was 0.96 as polynomial function. These results agreed with pervious results obtained by Ucgul et al., (2014), Ibrahmi et al., (2014), Aboukarima, (2007), Zang et al., (2018), and Moeenifar et al., (2014).

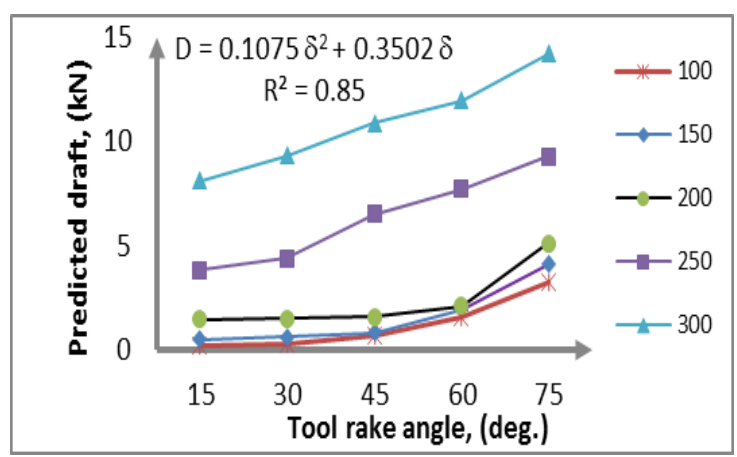

Figure 2. Predicting draft with rake angles under different depths.

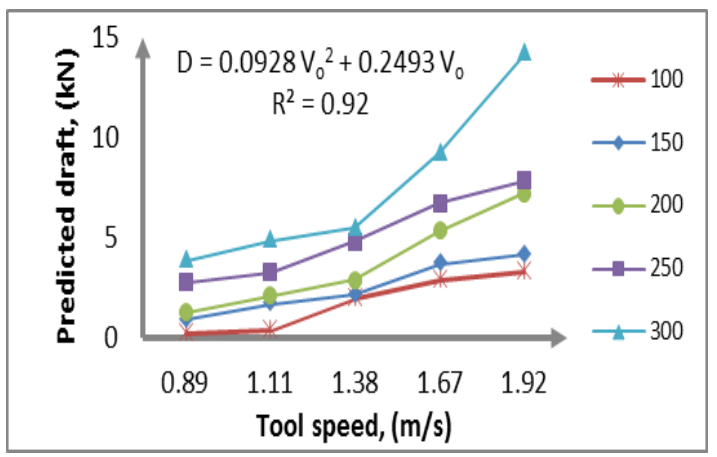

Figure 4. Predicting draft with speeds under different depths.

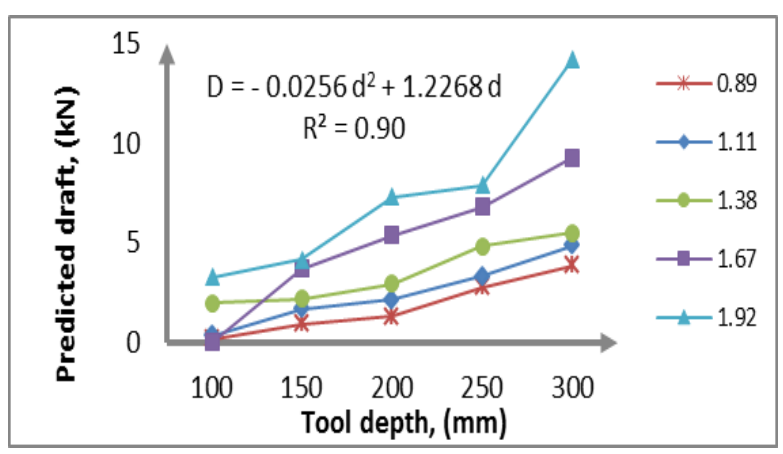

Figure 3. Predicting draft with tool depths under different speeds.

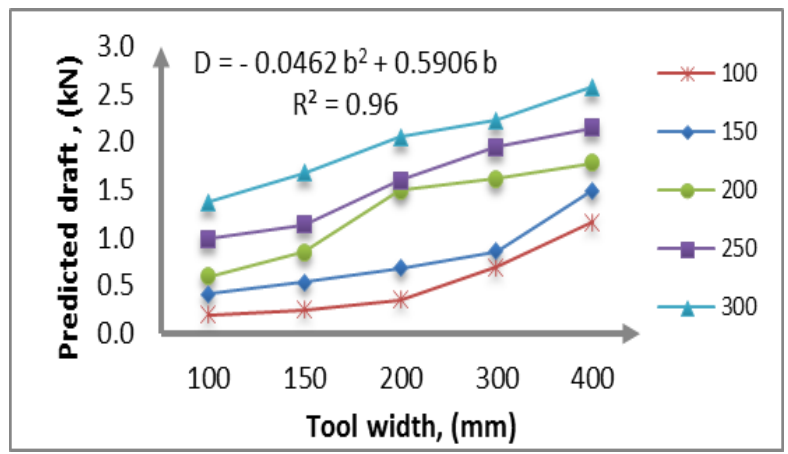

Figure 5. Predicting draft with tool widths under different depths.

Multi-regression analysis was performed for the data in Table (2) to driven a general relation between predicting the draft force with the examined parameters. The derived equation is:

$$
\mathrm{D}=1.63 \mathrm{~b}+2.13 \delta+2.8 \mathrm{~V}_{\mathrm{o}}+2.3 \mathrm{~d} \quad\left(\mathrm{R}^{2}=0.91\right)
$$

Where: 
$\mathrm{D}=$ draft, $(\mathrm{kN}), \mathrm{b}=$ tool width, $(\mathrm{m}), \delta=$ tool rake angle, $($ deg. $), \mathrm{V}_{\mathrm{o}}=$ tool speed, $(\mathrm{m})$, and $\mathrm{d}=$ tool depth, $(\mathrm{m})$.

Analysis of variance (Table 3) for predicting draft force with the four examined parameters could be summarized as the following:

- There were highly significant differences of predicting draft with relation to tool rake angle, tool depth, and tool speed. However, it was only significant with tool width.

- LSD test indicated that there were significant in the mean differences of predicting draft with the different levels of tool rake angles and tool depths. However, there was none significant with tool speeds and tool widths as shown in Table (4).

Table (2): Predicting draft with different levels of tool rake angles, tool depths, tool speeds, and tool widths at ( $15 \%$ moisture content and $12.91 \mathrm{kPa}$ soil cohesion).

\begin{tabular}{cc|ccccc}
\hline Depth (mm) & 100 & 150 & 200 & 250 & 300 \\
\hline & 100 & 0.19 & 0.41 & 0.59 & 0.98 & 1.37 \\
& 150 & 0.24 & 0.53 & 0.84 & 1.13 & 1.67 \\
Width & 200 & 0.35 & 0.68 & 1.49 & 1.59 & 2.05 \\
$(\mathrm{~mm})$ & 300 & 0.69 & 0.85 & 1.61 & 1.94 & 2.22 \\
& 400 & 1.16 & 1.49 & 1.78 & 2.14 & 2.57 \\
\hline & 15 & 0.20 & 0.52 & 1.48 & 3.85 & 8.14 \\
Rake & 30 & 0.30 & 0.66 & 1.51 & 4.41 & 9.32 \\
angle & 45 & 0.68 & 0.85 & 1.61 & 6.54 & 10.87 \\
(deg.) & 60 & 1.57 & 1.97 & 2.14 & 7.73 & 11.96 \\
& 75 & 3.25 & 4.14 & 5.11 & 9.28 & 14.21 \\
\hline & 0.89 & 0.18 & 0.90 & 1.28 & 2.77 & 3.85 \\
Speed & 1.11 & 0.35 & 1.68 & 2.13 & 3.30 & 4.86 \\
$(\mathrm{~m} / \mathrm{s})$ & 1.38 & 1.96 & 2.17 & 2.91 & 4.82 & 5.48 \\
& 1.67 & 2.86 & 3.68 & 5.35 & 6.76 & 9.23 \\
& 1.92 & 3.28 & 4.15 & 7.26 & 7.87 & 14.2 \\
\hline
\end{tabular}

Table (3): Analysis of variance for predicting draft force with respect to tool rake angles and tool depths.

\begin{tabular}{lccccc}
\hline Source & $\begin{array}{c}\text { Sum of } \\
\text { Squares }\end{array}$ & D.F & $\begin{array}{c}\text { Mean } \\
\text { Square }\end{array}$ & F & Sig. \\
\hline Corrected model & 632.443 & 16 & 39.528 & 12.465 & 0.00 \\
Intercept & 64.342 & 1 & 64.342 & 20.290 & 0.00 \\
Rake & 80.880 & 4 & 20.220 & 6.376 & 0.00 \\
Depth & 320.601 & 4 & 80.150 & 25.275 & 0.00 \\
Speed & 117.043 & 4 & 29.261 & 9.227 & 0.00 \\
Width & 33.027 & 4 & 8.257 & 2.604 & .045 \\
Error & 183.925 & 58 & 3.171 & & \\
Total & 1624.167 & 75 & & & \\
Corrected Total & 816.368 & 74 & & & \\
\hline
\end{tabular}

Table (4): LSD test for predicting daft with tool rake angles and tool depths. 


\begin{tabular}{cccccc}
\hline $\begin{array}{c}(\mathrm{I}) \\
\text { rake }\end{array}$ & $\begin{array}{c}(\mathrm{J}) \\
\text { rake }\end{array}$ & $\begin{array}{c}\text { Mean Difference } \\
(\mathrm{I}-\mathrm{J})\end{array}$ & $\begin{array}{c}(\mathrm{I}) \\
\text { Depth }\end{array}$ & $\begin{array}{c}(\mathrm{J}) \\
\text { depth }\end{array}$ & $\begin{array}{c}\text { Mean Difference } \\
(\mathrm{I}-\mathrm{J})\end{array}$ \\
\hline 30 & 45 & $-528.9524^{*}$ & 100 & 200 & $-430.1111^{*}$ \\
& 60 & $-526.6667^{*}$ & & 300 & $-904.3333^{*}$ \\
45 & 30 & $528.9524^{*}$ & 200 & 100 & $430.1111^{*}$ \\
& 60 & 2.2857 & & 300 & $-474.2222^{*}$ \\
60 & 30 & 526.6667 & 300 & 100 & $904.3333^{*}$ \\
& 45 & -2.2857 & & 200 & $474.2222^{*}$ \\
\hline
\end{tabular}

*The mean difference is significant at the .05 level.

\subsection{Model Experimentation for Power Requirements}

Figures from (6) to (9) show predicting power requirements under various levels of tool rake angles, tool depths, tool speeds, and tool widths, respectively. The effect of tool rake angle on predicting power requirements at different tool depths and at $(1.38 \mathrm{~m} / \mathrm{s}$ tool speed, $300 \mathrm{~mm}$ tool width, $15 \%$ moisture content, and $12.91 \mathrm{kPa}$ soil cohesion) is shown in Figure 6 . The highest values of predicting power requirements were obtained at the tool rake angle of $75^{\circ}$ under various tool depths.
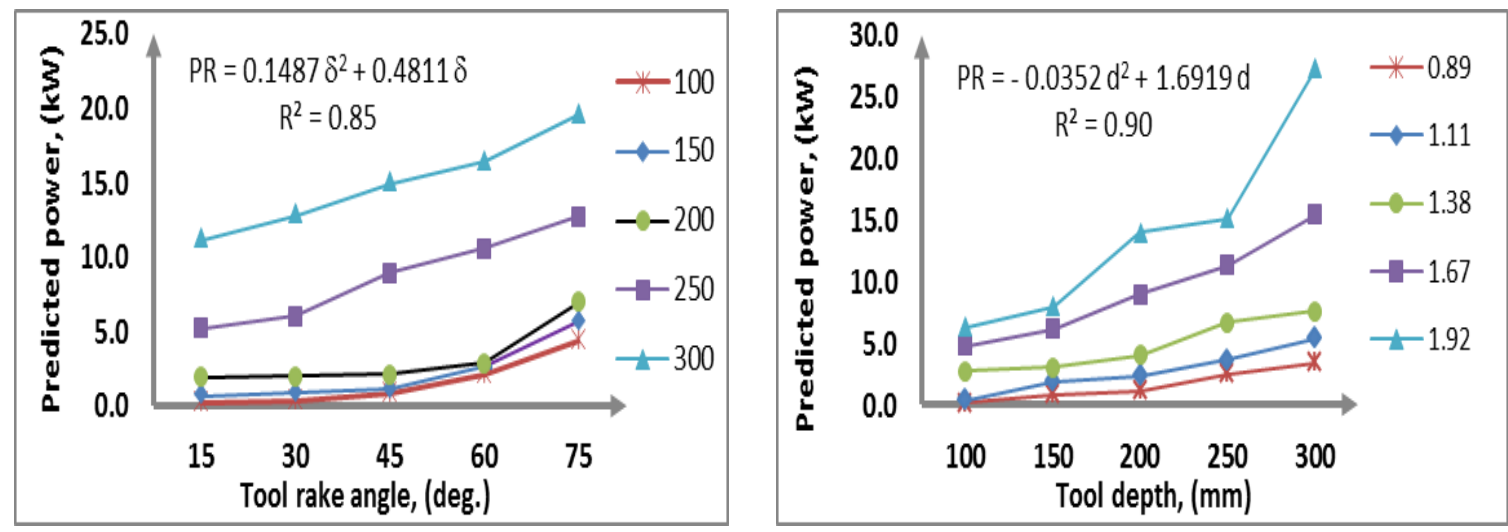

Figure 6. Predicting power with rake angles under Figure 7. Predicting power with tool depths under different depths.

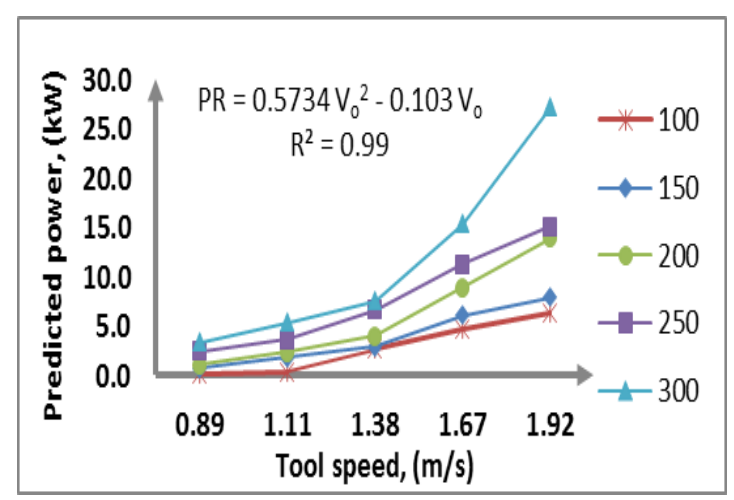

Figure 8. Predicting power with speeds under different depths. different speeds.

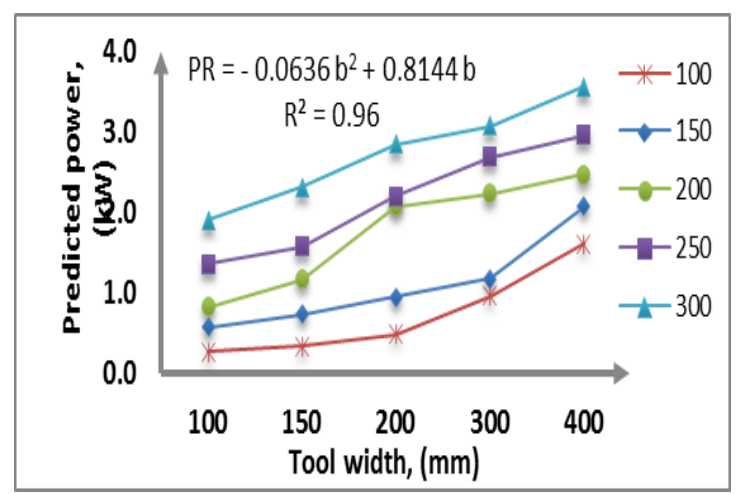

Figure 9. Predicting power with tool widths under different depths. 
However, the lowest values were obtained with the tool angle of $15^{\circ}$. At tool rake angle of $45^{\circ}$, the power requirements increased by $20 \%, 47 \%, 76 \%$, and $40 \%$ as the tool depths changed from 100 to $150 \mathrm{~mm}, 150$ to $200 \mathrm{~mm}, 200$ to $250 \mathrm{~mm}$, and 250 to $300 \mathrm{~mm}$, respectively. Correlation coefficient for predicting power requirements with tool rake angle was $85 \%$ as polynomial function. These results are in agreement with previous findings by Moeenifar et al., (2014), Akbarnia et al., (2014), Aboukarima, (2007), and Zang et al., (2018).

The effect of tool depth on predicting power requirements at different tool speeds and at $\left(45^{\circ}\right.$ tools rake angle, $300 \mathrm{~mm}$ tool width, $15 \%$ moisture content, and $12.91 \mathrm{kPa}$ soil cohesion) is shown in Figure 7. It indicated that the increase in tool depth from $100 \mathrm{~mm}$ to $300 \mathrm{~mm}$ resulted in increasing of predicting power requirements by about $96 \%, 93 \%, 65 \%, 69 \%$, and $77 \%$ for tool speeds of $0.89,1.11,1.38,1.67$, and $1.92 \mathrm{~m} / \mathrm{s}$, respectively. At high level of tool depth, the predicting power requirements increased by $27 \%, 29 \%, 51 \%$, and $44 \%$ when the tool speed changed from 0.89 to $1.92 \mathrm{~m} / \mathrm{s}$.

Correlation coefficient for predicting power requirements with tool depth was $90 \%$ as polynomial function. These results are in agreement with pervious findings by Akbarnia et al. (2014), Aboukarima, (2007), Zang et al., (2018), and Moeenifar et al., (2014).

The effect of tool speed on predicting power requirements under different levels of tool depths and at (rake angle of $45^{\circ}$, tool width of $300 \mathrm{~mm}, 15 \%$ moisture content, and $12.91 \mathrm{kPa}$ soil cohesion) is showed in Figure 8. Results showed similar trends as with tool depths. The increase in tool speed from 0.89 to $1.93 \mathrm{~m} / \mathrm{s}$ resulted in increasing in the power requirements by $97 \%$, $90 \%, 92 \%, 84 \%$, and $88 \%$ for tool depths of 100, 150, 200, 250, and $300 \mathrm{~mm}$, respectively. Correlation coefficient for predicting power requirements with tool speed was $99 \%$ as polynomial function. These results are in agreement with pervious findings by Akbarnia et al. (2014), Aboukarima, (2007), Zang et al., (2018), and Moeenifar et al., (2014).

The effect of tool width on predicting power requirements under different levels of tool depths and at $\left(45^{\circ}\right.$ of rake angle, tool speed of $1.39 \mathrm{~m} / \mathrm{s}, 15 \%$ moisture content, and $12.91 \mathrm{kPa}$ soil cohesion) is shown in Figure 9. The increase in tool width caused an increase in the predicting power requirements under different tool depths. The percentage changes in the predicting power requirements with different tool widths were $86 \%, 85 \%, 83 \%, 69 \%$, and $45 \%$ as the tool depths increased from 100 to $300 \mathrm{~mm}$. Correlation coefficient for predicting power requirements with tool width was $96 \%$ as polynomial function. These results are in agreement with pervious findings by Akbarnia et al. (2014), Aboukarima, (2007), Zang et al., (2018), and Moeenifar et al., (2014).

Multi-regression analysis was performed for the data in Table (5) to driven a general relation between predicting power requirements with respect to examined parameters. The derived equation is:

Where:

$$
\mathrm{PR}=3.1 \mathrm{~b}+2.82 \delta+4.7 \mathrm{~V}_{\mathrm{o}}+4.12 \mathrm{~d} \quad\left(\mathrm{R}^{2}=0.90\right)
$$

$\mathrm{PR}=$ power requirements, $(\mathrm{kW}), \mathrm{b}=$ tool width, $(\mathrm{m}), \delta=$ tool rake angle, (deg.), $\mathrm{V}_{\mathrm{o}}=$ tool speed, $(\mathrm{m})$, and $\mathrm{d}=$ tool depth, $(\mathrm{m})$.

Analysis of variance (Table 6) for predicting power requirements with respect to tool rake angles, tool depths, tool speeds, and tool widths could be summarized as the following: 
- There were highly significant differences of predicting power requirements with relation to tool rake angle, tool depth, and tool speed. However, it was none significant with tool width.

- LSD test indicated that there were significant in the mean differences of predicting power requirements with the different levels of tool rake angles, tool speeds, and tool widths. However, there was none significant with tool depths as shown in Table (7).

Table (5): Predicting power requirements from running the program of modified model with different levels of tool rake angles, tool depths, tool speeds, and tool widths at (15\% moisture content and $12.91 \mathrm{kPa}$ soil cohesion).

\begin{tabular}{cl|lcccc}
\hline Depth (mm) & 100 & 150 & 200 & 250 & 300 \\
\hline & 100 & 0.26 & 0.57 & 0.81 & 1.35 & 1.89 \\
& 150 & 0.33 & 0.73 & 1.16 & 1.56 & 2.30 \\
Width & 200 & 0.48 & 0.94 & 2.06 & 2.19 & 2.83 \\
$(\mathrm{~mm})$ & 300 & 0.95 & 1.17 & 2.22 & 2.68 & 3.06 \\
& 400 & 1.60 & 2.06 & 2.46 & 2.95 & 3.55 \\
\hline & 15 & 0.28 & 0.72 & 2.04 & 5.31 & 11.23 \\
Rake & 30 & 0.41 & 0.91 & 2.08 & 6.09 & 12.86 \\
angle & 45 & 0.94 & 1.17 & 2.22 & 9.03 & 15.00 \\
$($ deg.) & 60 & 2.17 & 2.72 & 2.95 & 10.67 & 16.50 \\
& 75 & 4.49 & 5.71 & 7.05 & 12.81 & 19.61 \\
\hline & 0.89 & 0.16 & 0.80 & 1.14 & 2.47 & 3.43 \\
Speed & 1.11 & 0.39 & 1.86 & 2.36 & 3.66 & 5.39 \\
$(\mathrm{~m} / \mathrm{s})$ & 1.38 & 2.70 & 2.99 & 4.02 & 6.65 & 7.56 \\
& 1.67 & 4.78 & 6.15 & 8.93 & 11.29 & 15.41 \\
& 1.92 & 6.30 & 7.97 & 13.94 & 15.11 & 27.26 \\
\hline
\end{tabular}

Table (6): Analysis of variance of predicting power requirements with respect to rake angles, depths, speeds, and widths.

\begin{tabular}{l|ccccc}
\hline Source & $\begin{array}{c}\text { Sum of } \\
\text { Squares }\end{array}$ & D.F & $\begin{array}{c}\text { Mean } \\
\text { Square }\end{array}$ & F & Sig. \\
\hline Corrected model & 1643.916 & 16 & 102.745 & 13.547 & 0.000 \\
Intercept & 163.051 & 1 & 163.051 & 21.499 & 0.000 \\
Rake & 154.117 & 4 & 38.529 & 5.080 & 0.001 \\
Depth & 657.632 & 4 & 164.408 & 21.678 & 0.000 \\
Speed & 583.092 & 4 & 145.773 & 19.221 & 0.000 \\
Width & 62.884 & 4 & 15.721 & 2.073 & 0.096 \\
Error & 439.878 & 58 & 7.584 & & \\
Total & 3810.355 & 75 & & & \\
Corrected Total & 2083.794 & 74 & & & \\
\hline
\end{tabular}


Table (7): LSD test for predicting power requirements with tool rake angles and tool speeds.

\begin{tabular}{cccccc}
\hline $\begin{array}{c}(\mathrm{I}) \\
\text { rake }\end{array}$ & $\begin{array}{c}(\mathrm{J}) \\
\text { rake }\end{array}$ & $\begin{array}{c}\text { Mean Difference } \\
(\mathrm{I}-\mathrm{J})\end{array}$ & $\begin{array}{c}(\mathrm{I}) \\
\text { speed }\end{array}$ & $\begin{array}{c}(\mathrm{J}) \\
\text { speed }\end{array}$ & $\begin{array}{c}\text { Mean Difference } \\
(\mathrm{I}-\mathrm{J})\end{array}$ \\
\hline 30 & 45 & $-528.9524^{*}$ & 1.10 & 1.39 & -.6022 \\
& 45 & -.6667 & & 1.67 & $-1.7067^{*}$ \\
45 & 60 & $-1.8222^{*}$ & 1.39 & 1.10 & .6022 \\
& 30 & .6667 & & 1.67 & $-1.1044^{*}$ \\
60 & 60 & $-1.1556^{*}$ & 1.67 & 1.10 & $1.7067^{*}$ \\
& 30 & $1.8222^{*}$ & & 1.39 & $1.1044^{*}$ \\
\hline
\end{tabular}

*The mean difference is significant at the .05 level.

\section{CONCLUSION}

Model experimentation for predicting draft and power requirements of simple tillage tools was carried out based on Sohne's model. Four tool operating parameters were chosen to be cases for model experimentation. Experimentation process was carried out using simulation model modified by Afify et al. (2020). It was also performed through running the modified program using real data as inputs of soil parameters. Results of model experimentation may be summarized as the following:

- The model could be predicting daft and power requirements by accuracy of more than $90 \%$ for the four examined parameters.

- Correlation coefficient of both predicting draft and power requirements with respect to examined parameters were $85 \%, 90 \%, 99 \%$, and $96 \%$ for rake angle, tool depth, tool speed, and tool width, respectively.

- There were highly significant differences of predicting draft and power requirements with respect to all examined parameters.

- There were significant in the mean differences of predicting draft and power requirements with the different levels of the examined parameters using LDS test.

- General equations were derived between predicting draft and power requirements with the different examined parameter.

\section{REFERENCES}

Abd EI Wahed, M. A. (2007). Draft models of chisel plow based on simulation using artificial neural networks. Misr J. Agr. Eng., 24(1): 42-61.

Abu-Hamdeh, N.H. and Reeder R.C. (2003). A nonlinear 3D finite element analysis of the soil forces acting on a disk plow. Soil and Tillage Research74:115-124.

Afify, M.T. (1999). Development of a combined tillage planting machine for row crops. Ph.D. Thesis. Agronomy and Agri. Eng. Department. College of Agriculture at Moshtohor, Zagazig University (Benha Branch). 
Afify, M.T., El-Haddad Z. A. and Lamia D. A. A. (2020). Modeling the effect of soil-tool interaction on draft force using visual basic. Annals of Agri. Sci., Moshtohor. Vol. 58 (2) (2020): 223-232.

Afify, M.T., Kushwaha R.L., Milne W.G., El-Haddad Z.A., and El-Ansary M.Y. (1999). Power requirements of individual components of single unit till-planting systems. American Society of Agricultural Engineers (ASAE) paper no. 99-1087. 1999.

Akbarnia, A, Mohammadi A., Farhani F. and Alimardani R. (2014). Simulation of draft of winged share tillage tool using artificial neural network model. Agric. Eng. Int. CIGR Journal. 16(4):1-10.

Al-Hamed, S., Wahby M., Aboukarima A. and Ahmed K. (2014). Development of a computer program using visual basic for predicting performance parameters of tillage implements. Misr J. Ag. Eng., 31 (3): 1157 - 1190.

ASAE Standards (1998). Agricultural Machinery Management data (EP496.4 MAR94). St. Joseph, MI:ASAE, pp. 354-367.

Bocken N.M.P., Schuitc C.S.C. and Kraaijenhagen C. (2018). Experimenting with circular business model: Lessons from eight cases. Environmental Innovation and Societal Transitions Journal. Elsevier B.V. 2018

CAPMS (2019). Cultivated Area in Egypt. Annual book of central agency for public mobilization and statistics. (In Arabic).

Gill W.R., and Vanden B. (1968). Assessment of the dynamic properties of soils. Chapter 3 in soil dynamics in tillage and traction. Agriculture Handbook No. 316, pp. 55116.Washington, D.C.:U.S. Government Printing Office.

Ibrahmi, A., Hatem B. and Aref M. (2014). Soil-blade orientation effect on tillage forces determined by 3D finite element models. Spanish Journal of Agricultural Research. 12(4): 941-951.

Kheiralla, F.A., Yahia A., Zohadie M. and Ishak W. (2004). Modelling of power and energy requirements for tillage implements operating on Serdang sandy clay loam, Malaysia. Soil and Tillage Research, 78: 21-34.

Moeenifar, A., Mousavi-Seyedi S. R. and Kalantari D. (2014). Influence of tillage depth, penetration angle and forward speed on the soil/thin-blade interaction force. Agricultural Engineering International: The CIGR Journal, 161: 69-74.

Rosa, U. A. (1997). Performance of narrow tillage tools with inertial and strain rate effects. Ph.D. Thesis. Department Agricultural and Bioresource Engineering. University of Saskatchewan. Canada. 
Shahgholi, G., Kanyawi N. and Kalantari d. (2019). Modeling the effects of narrow blade geometry on soil failure draught and vertical forces using discrete element method. Research Article. YYÜ TAR BİL DERG, 29(1): 24-33.

Sohne, W. (1956). Some principles of soil mechanics as applied to agricultural engineering. Grundlagen der Landteckink 7:11-27 (NIAE Translation 53).

Tong, J. and Moayad B. Z. (2006). Effects of rake angle of chisel plow on soil cutting factors and power requirements: A computer simulation. Soil \& Tillage Res., 88 (1-2): 55-64.

Ucgul, M, Fielke J. and Saunders C. (2014). 3D DEM tillage simulation: Validation of a hysteretic spring (plastic) contact model for a sweep tool in a cohesionless soil. Soil \& Tillage Research 144:220-227.

Zhang, L., Cai Z., Wang L., Zhang R. and Liu H. (2018). Coupled Eulerian-Varangian finite element method for simulating soil-tool interaction. Science Direct journal. 


\section{نموذج تجريبي للتنبؤ بقوة الثد ومتطلبات القدرة لمعدات الحراثة البسيطة}

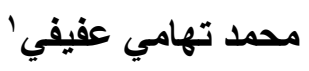

'مدرس بقسم هندسة النظم الزر اعية و الحيوية ـ كلية الزر اعة ـ جامعة بنها ـ مصر.

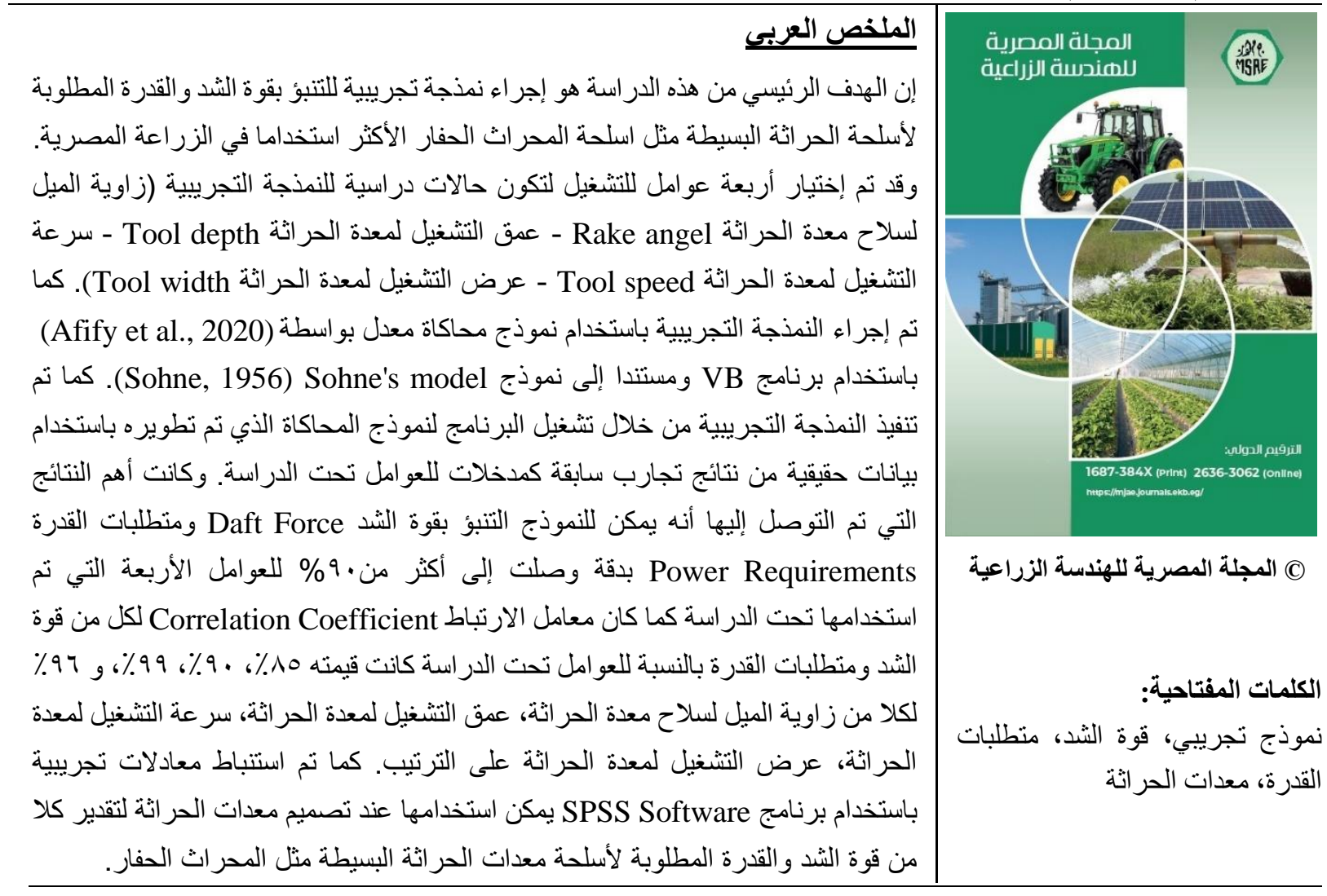

